\title{
ARTIKELEN
}

\section{Islamitisch begraven in Nederland ten tijde van Covid-19}

\author{
Khadija Kadrouch-Outmany
}

\section{Het persoonlijke verhaal: waar begraven?}

\section{Inleiding}

Een kenmerk van de Turkse en Marokkaanse gastarbeiders die naar Nederland kwamen in de jaren zestig en zeventig van de vorige eeuw is dat hun verblijf tijdelijk zou zijn. Dat velen van hen niettemin zijn gebleven en hun gezinnen hebben laten overkomen in de jaren tachtig, was niet zozeer een bewuste keuze voor een toekomst in Nederland, maar een verlenging van een tijdelijk arbeidsbestaan. Hoezeer ook duidelijk is dat terugkeer naar het land van herkomst niet meer aan de orde is - al was het maar omdat de volgende generaties zijn geboren in Nederland en zich hier hebben gevestigd -, toch blijft de wens tot terugkeer bestaan. Dat blijkt vooral uit de keuze van begraafplaats. De eerste generatie wil dan 'terug' en begraven worden in het land van herkomst. Uit mijn promotieonderzoek naar islamitisch begraven, dat ik uitvoerde tussen 2010 en 2013, bleek dit ook te gelden voor de tweede generatie: het gevoel emotioneel niet te behoren tot Nederland (a sense of belonging) en de wens om terug te keren naar het land van herkomst waren voor hen de belangrijkste overwegingen om te kiezen voor een begraafplaats aldaar. ${ }^{1}$

Een kleine tien jaar later is er echter veel veranderd. De tweede generatie blijkt tegenwoordig steeds vaker te kiezen voor een begrafenis in Nederland. In Marokkaans- en Turks-Nederlandse gezinnen werden discussies over wensen rondom begraven nauwelijks gevoerd. In de afgelopen jaren is hier echter langzaam een verschuiving in ontstaan. Zo spraken verschillende Nederlandse columnisten van Marokkaanse en Turkse origine zich uit over hun wens om in Nederland begraven te worden. ${ }^{2}$ Ook Ahmed Aboutaleb, burgemeester van Rotterdam, heeft zich meerdere malen publiekelijk uitgesproken over zijn wens om in Nederland begraven te worden. ${ }^{3}$ In meer persoonlijke context worden deze gesprekken ook

1 K. Kadrouch-Outmany, Islamic Burials in the Netherlands and Belgium. Legal, Religious and Social Aspects, Leiden 2014, p. 148-150.

2 'Toch maar hier begraven worden?', NRC Handelsblad 15 april 2020; 'Afscheid zonder omhelzing', Volkskrant Magazine 15 oktober 2016.

3 'Als ik hier sterf, begraaf me dan hier', Algemeen Dagblad 5 januari 2019. Toen hij in 2007 staatssecretaris van Sociale Zaken en Werkgelegenheid werd, trok Aboutaleb in de Tweede Kamer zijn Nederlandse paspoort uit zijn jasje en riep dat hij Nederlands was en in Nederland begraven wenste te worden. Deze uitspraak moet gezien worden in de discussie die destijds, op initiatief van de Partij voor de Vrijheid, werd gevoerd met betrekking tot de dubbele nationaliteit van bewindslieden en Kamerleden. 
gevoerd. Tien jaar geleden was dat nog anders. Onder mijn eigen respondenten waren er destijds meerderen die vertelden dit gesprek niet aan te willen of durven gaan met hun ouders vanwege het taboe dat er volgens hen op rustte. ${ }^{4}$ Tegenwoordig echter gaan ook zij thuis de discussie aan en spreken zich openlijk uit over hun wens om, in tegenstelling tot hun ouders en grootouders, in Nederland begraven te worden.

De keuze voor de locatie van de begraafplaats is met het voortschrijden van de tijd steeds concreter geworden, nu de eerste generatie de leeftijd heeft bereikt dat zij begint te overlijden. Zoals gezegd, is voor de meesten van hen de keuze helder; zij worden gerepatrieerd naar hun land van herkomst. Niettemin zijn er ook Nederlandse moslims die in Nederland worden begraven. Deze groep is klein, maar groeit gestaag. Voor deze groep wordt binnen de moslimgemeenschap getracht voorzieningen te treffen om hun begrafenis op islamitische wijze te laten plaatsvinden. Dat heeft echter enige voeten in de aarde, zoals in de volgende paragraaf zal blijken.

Het proces van islamitisch begraven in Nederland is er een van de lange adem: het kost tijd om in Nederland locaties aan te werven voor islamitische begraafplaatsen en om de voorzieningen te treffen en juridische regels aan te passen om de begrafenissen op islamitische wijze te laten plaatsvinden. Deze geleidelijkheid liep min of meer in de pas met de toename van Nederlandse moslims die in Nederland begraven willen worden. Maar met de Covid-19-crisis kwam deze kwestie in een stroomversnelling. Op 14 maart 2020 werden alle vluchten naar Marokko opgeheven, waardoor in de daaropvolgende maanden de lichamen van Marokkaanse Nederlanders niet meer gerepatrieerd konden worden. In de periode van 14 maart tot 10 juni 2020 zijn naar schatting 300 tot 350 Marokkaanse Nederlanders in Nederland begraven. ${ }^{5}$ Turkije had in diezelfde week van maart ook alle passagiersvluchten naar Turkije opgeheven, maar overledenen konden nog wel gerepatrieerd worden, zij het met cargovluchten en zonder de begeleiding van nabestaanden. Dat verklaart wellicht dat het aantal Turkse Nederlanders dat in Nederland is begraven in de periode van 14 maart tot 10 juni 2020 aanzienlijk lager is dan het aantal Marokkaanse Nederlanders: de schatting ligt tussen de 30 en 40 personen.

Binnen de moslimgemeenschap heeft de sluiting van het luchtruim geleid tot een verhoogde activiteit in het aanleggen van islamitische begraafplaatsen. Maar alvorens we dat bespreken, dienen we nader in te gaan op de praktische en juridische haken en ogen die daarmee gepaard gaan.

$4 \quad$ Kadrouch-Outmany 2014, p. 104.

5 Deze schattingen zijn gebaseerd op de gezamenlijke cijfers van de uitvaartondernemers die gecontracteerd zijn bij de Marokkaanse en Turkse repatriëringsverzekeringen (Post Mortem Repatriëringen, Arrahma uitvaart en ISN Diyanet Nederland) en jaarlijkse ruim $80 \%$ van de repatriëringen naar deze landen begeleiden en uitvoeren. 


\section{Het praktische verhaal: de islamitische begrafenis}

\section{Nederlandse moslims en hun begraafwensen}

Het aantal moslims in Nederland is moeilijk te definiëren in verband met verschillende methoden voor dataverzameling, maar wordt tegenwoordig op 875.000 geschat. ${ }^{6}$ Het overgrote deel hiervan, zo'n $85 \%$, is soennitisch. Het aantal sjiieten wordt geschat op 45.000 tot $90.000 .{ }^{7}$ De soennitische en sjiitische tak vertegenwoordigen de twee grootste stromingen van de islam en vanuit hun perspectief zijn twee andere stromingen die zich islamitisch noemen, namelijk de alevitische en de ahmadiyya-gemeenschappen, controversieel. De ahmadiyya hebben ongeveer 10.000 aanhangers in Nederland, de alevieten ongeveer 80.000. ${ }^{8}$

Het verschil tussen deze vier stromingen zit voornamelijk in de opvattingen rondom de legitimiteit van de Profeet en zijn opvolgers. Soennitische moslims erkennen de legitimiteit van de eerste vier opvolgers van Mohammed, terwijl sjiitische moslims geloven dat het religieuze en politieke gezag van Mohammed is doorgegeven aan zijn nakomelingen. ${ }^{9}$ 'Aleviet' is een term die gebruikt wordt om een aantal heterogene sociaal-religieuze gemeenschappen in Turkije en de Balkan aan te duiden, die in de twintigste eeuw een gemeenschappelijke transregionale identiteit begonnen te delen die alevisme wordt genoemd. Alevieten worden soms gezien als een tak van de sjiitische islam. ${ }^{10}$ De ahmadiyya vormen een messianistische beweging die in 1889 door Mirza Ghulam Ahmad in Qadian (India) werd opgericht. De ahmadiyya werden bij Pakistaanse wet in 1974 tot niet-moslim verklaard vanwege hun verzet tegen de islamitische opvatting dat Mohammed de laatste profeet is geweest. ${ }^{11}$

Onder deze vier gemeenschappen vinden in Nederland jaarlijks naar schatting 1500 islamitische begrafenissen plaats. ${ }^{12}$ Geschat wordt dat minder dan de helft hiervan soennitische moslims zijn. Het grootste deel van de moslims dat zich laat begraven in Nederland betreft sjiieten, ahmadiyya en alevieten. Met name ahmadiyya-moslims (van Pakistaanse en Surinaamse achtergrond) gaven veelvuldig aan dat zij niet in het land van herkomst begraven wilden worden, waar zij door de soennitische meerderheid werden of worden onderdrukt. Ook de alevieten (veelal vanuit de Balkan en van Turkse komaf) en sjiieten (onder andere uit Syrië, Irak, Iran, Afghanistan en Jemen) kiezen in de regel voor een begrafenis in Nederland. In sommige van deze gevallen is repatriëring simpelweg uitgesloten, omdat in het herkomstland een (burger)oorlog gaande is. De afgelopen jaren lijkt er echter, zoals gezegd, een verschuiving plaats te vinden en spreken steeds meer

7 W. Shadid \& P.S. van Koningsveld, Islam in Nederland en België, Leuven 2009, p. 39-49.

8 Shadid \& Van Koningsveld 2009, p. 39-49.

9 J.L. Esposito, The Oxford Dictionary of Islam, New York 2003, p. 292.

10 Esposito 2003, p. 14.

11 Esposito 2003, p. 11-12.

12 Deze schatting is gebaseerd op de cijfers van de Landelijke Organisatie Begraafplaatsen (LOB). Bij de LOB zijn 575 organisaties aangesloten, die gezamenlijk circa 2200 begraafplaatsen beheren. In Nederland zijn ongeveer 4400 begraafplaatsen. De bij LOB aangesloten begraafplaatsen verzorgen gezamenlijk ongeveer $75 \%$ van alle begrafenissen op jaarbasis. 
soennitische moslims, voornamelijk van Marokkaanse en Turkse komaf, zich uit over hun wens om in Nederland begraven te worden. De meest recente initiatieven voor islamitische begraafplaatsen komen dan ook vanuit deze gemeenschappen. Daar zal ik in de hiernavolgende paragrafen nader op ingaan.

\section{De islamitische begrafenis}

Een islamitische begrafenis kenmerkt zich in het algemeen door een viertal rituelen die, afhankelijk van de stroming waartoe men behoort, soms in een iets andere uitvoering plaatsvinden. De overledene wordt ritueel gewassen met water, door naasten of door een daartoe aangestelde 'wasgroep'. Het lichaam wordt daarna in witte lijkwaden gewikkeld. Vervolgens vindt er voor de overledene een begrafenisgebed plaats, in de moskee of op de begraafplaats. En ten slotte wordt de overledene begraven, bij voorkeur dezelfde dag en in ieder geval binnen 24 uur. De teraardebestelling vindt volgens de islamitische voorschriften bij voorkeur plaats zonder kist, in een graf voor één persoon, dat ligt in de richting van Mekka. Het graf dient niet geruimd te worden in verband met het geloof in de wederopstanding op de Dag des Oordeels. Met name dit laatste, de kwestie van eeuwigdurende graven of graven met een onbepaalde grafrust, is een terugkerende kwestie in relatie tot islamitisch begraven in Nederland. Minder dan $10 \%$ van de Nederlandse gemeenten biedt namelijk de mogelijkheid om graven af te nemen voor een onbepaalde tijd. In alle andere gevallen worden graven voor een bepaalde tijd uitgegeven, met de mogelijkheid tot verlenging.

\section{De inrichting van islamitische percelen op begraafplaatsen}

In het kader van de Nederlandse openbare orde is het begraven onderworpen aan nationale en lokale regels. In deze paragraaf schets ik kort de historische ontwikkelingen die het huidige Nederlandse begraaflandschap hebben gevormd, en vervolgens bespreek ik het bestaan van islamitische percelen op openbare begraafplaatsen, de aanleg van de eerste islamitische begraafplaats in Nederland, en het meest recente initiatief voor een islamitische begraafplaats in Zuidlaren.

\section{- Begraafplaatsen en percelen}

In Nederland kunnen begraafplaatsen zowel openbaar als privé zijn. Sinds 1827 zijn gemeenten verplicht om te zorgen voor de aanleg van een openbare begraafplaats. ${ }^{13}$ Een derde van alle begraafplaatsen is in eigendom, in beheer en onder financiering van gemeenten. De rest zijn zogenoemde bijzondere begraafplaatsen, die eigendom zijn van verschillende religieuze groepen of van particuliere rechtspersonen. ${ }^{14}$ Het recht om religieuze begraafplaatsen te realiseren werd ingesteld met de invoering van de Begraafwet uit 1869. Naast de aanleg van religieuze begraafplaatsen bepaalde artikel 19 van deze wet het recht op een perceel

13 Art. 13 Begraafwet, Stb. 1869, 65.

14 R. van den Breemer \& M. Maussen, 'On the Viability of State-Church Models: Muslims Burial and Mosque Building in France and the Netherlands', Journal of Immigrant \& Refugee Studies 2012/10, p. 283. 
voor religieuze kerkgenootschappen die zich geen eigen begraafplaats konden veroorloven:

'De algemeene begraafplaatsen worden zóó aangelegd, dat, op verlangen van het bestuur eener kerkelijke gemeente die geen eigen begraafplaats bezit, de lijken van de leden dier kerkelijke gemeente in een afzonderlijk, uitsluitend voor hen bestemd gedeelte kunnen worden begraven. Ieder zoodanig gedeelte heeft een afzonderlijken ingang, behoudens dat één hoofdingang voor de geheele begraafplaats kan dienen. De inrigting van elk deze gedeelten wordt door het gemeentebestuur geregeld, na daarop het bestuur van de betrokken kerkelijke gemeenten te hebben gehoord. ${ }^{15}$

Dit recht gold voor katholieken, protestanten en joden. Tegenwoordig wordt hierop ook een beroep gedaan door moslims en aanhangers van andere religies. Het begraaflandschap in Nederland biedt daardoor een breed scala aan mogelijkheden, waaronder verschillende religieuze begraafplaatsen, religieuze percelen op gemeentelijke openbare begraafplaatsen, en ook gemeentelijke openbare delen op religieuze begraafplaatsen. ${ }^{16}$

\section{- Islamitische percelen op openbare begraafplaatsen}

Er bestaan in Nederland twee islamitische particuliere begraafplaatsen en tussen de 85 en 90 islamitische percelen op verschillende (openbare) begraafplaatsen. Het aantal islamitische percelen is de afgelopen jaren gestegen. ${ }^{17}$ Steeds meer gemeenten realiseerden op eigen initiatief, op verzoek van een islamitische gemeenschap of op verzoek van een politieke partij een islamitisch perceel op de openbare begraafplaats. De verwachting was immers dat moslims die hier geboren zijn en opgroeien grotendeels in Nederland hun laatste rustplaats zouden zoeken.

De aanleg en inrichting van een islamitisch perceel verschillen aanzienlijk van de aanleg van een islamitische begraafplaats. Islamitische percelen op openbare begraafplaatsen bestaan al tientallen jaren in Nederland. De allereerste werd in 1932 aangelegd op de begraafplaats aan de Kerkhoflaan in Den Haag. ${ }^{18}$ Islamitische percelen zijn afgescheiden van de rest van de begraafplaats door een heg of een pad, en de graven liggen in de richting van Mekka. De regels die van toepassing zijn op het islamitische perceel, zijn dezelfde als die voor het publieke deel van de begraafplaats, namelijk de gemeentelijke verordening en het begraafplaatsreglement. Concreet betekent dit bijvoorbeeld dat wanneer er op het publieke gedeelte van de begraafplaats geen mogelijkheid bestaat tot uitgifte van graven voor onbepaalde tijd, dat ook geldt voor het islamitische perceel. In tegenstelling tot een particuliere begraafplaats kan een openbare begraafplaats boven-

Art. 19 Begraafwet, Stb. 1869, 65.

Van den Breemer \& Maussen 2012, p. 283.

Toen ik mijn onderzoek uitvoerde tussen 2010 en 2013, bestonden er ongeveer 75 percelen.

A. Ryad, 'Among the Believers in the Land of the Colonizer: Mohammed Ali van Beetem's Role among the Indonesian Community in the Netherlands in the Interwar Period', Journal of Religion in Europe 2012, p. 293. 
dien niemand de mogelijkheid ontzeggen om er begraven te worden. Onder moslims bestaan echter discussies over de vraag of aanhangers van bepaalde islamitische stromingen toegang moeten krijgen tot elkanders percelen, wat heeft geleid tot onverkwikkelijke situaties.

Illustratief in dit verband is het islamitische perceel op het gemeentelijk kerkhof van Westduin in Den Haag, dat in 1994 is opgericht en verdeeld is over zeven verschillende islamitische organisaties die tot drie verschillende islamitische stromingen behoren. De gemeente stelde dat deze islamitische organisaties recht hebben op hun eigen percelen, omdat ze niet als één kerkelijke gemeenschap konden worden opgevat. Het ene islamitische perceel bestaat uit zeven afzonderlijke subpercelen die intern van elkaar zijn gescheiden door stoeptegels of door een heg. Elk van de zeven percelen is bestemd voor soennitische, sjiitische of ahmadiyyamoslims. Alleen leden van de zeven specifieke organisaties kunnen op 'hun' perceel worden begraven. Moslims die niet tot een van deze zeven organisaties behoren, maar toch begraven willen worden in het islamitische deel van deze begraafplaats, kunnen worden begraven in het 'publieke islamitische deel' van het islamitische perceel, wat dus feitelijk het achtste islamitische perceel vormt op deze begraafplaats. Deze versplintering heeft zich in een aantal andere gemeenten voorgedaan en lijkt kenmerkend te zijn voor Nederland vanwege een historische traditie van afzonderlijke percelen voor verschillende kerkgenootschappen. ${ }^{19}$

\section{Islamitische begraafplaatsen}

Hoewel de aanleg van islamitische percelen in de afgelopen tien jaren is toegenomen, was dit tot voor kort niet het geval voor particuliere islamitische begraafplaatsen. Eerdere studies suggereerden dat de verklaring hiervoor lag in de voorkeur die moslims geven aan 'het begraven op een openbare begraafplaats in plaats van het investeren van middelen in een particuliere (en kostbare) begraafplaats'. ${ }^{20}$ Ik meen echter, zoals ik hiervoor al stelde, dat met name het gevoel emotioneel niet te behoren tot Nederland (a sense of belonging) en de wens om terug te keren naar het land van herkomst een doorslaggevende rol speelden bij het uitblijven van meer islamitische begraafplaatsen.

De eerste islamitische begraafplaats werd in 2007 in Almere gerealiseerd. Door de Stichting Almeerse Moslims Al Raza werd een stuk grond aangekocht naast de bestaande openbare begraafplaats, om daar vervolgens een eigen islamitische begraafplaats aan te leggen. Op de islamitische begraafplaats worden alleen graven voor onbepaalde tijd uitgegeven. Bovendien mogen alleen overledenen die 'moslims zijn volgens de islamitische godsdienstwet' op deze begraafplaats worden begraven. Wie hiermee bedoeld wordt, is bepaald door het bestuur van de organisatie. In geval van twijfel kan het bestuur zijn moefti (islamitische geleerde) om advies vragen. Duidelijk is wel dat het voor leden van de ahmadiyya strikt verboden is om op deze begraafplaats begraven te worden. Zo vertelde de voorzitter van de stichting het volgende: 
'Ahmadiyya worden als niet-moslims beschouwd en mogen daarom niet begraven worden op een islamitische begraafplaats.'

De wrijving tussen ahmadiyya en soennieten kwam heel sterk naar voren in de interviews die ik hield onder moslims met een Surinaamse achtergrond. Binnen families werden uitvaarten om deze reden regelmatig een proces van in- en uitsluiting. Zo vertelde een van mijn respondenten de volgende illustratieve anekdote:

'Toen mijn opa overleed werd het begrafenisgebed gehouden in de moskee. We hadden allemaal kort daarvoor afscheid van hem genomen voordat hij in de kist werd gelegd. Toen de mannen bij elkaar kwamen voor het gebed riep de imam alle vrouwen en ahmadiyya-leden op om te vertrekken. Verschillende familieleden van mijn opa zíjn ahmadiyya, en voelden zich hierdoor enorm te kijk gezet.'

Ten tijde van mijn onderzoek tussen 2010 en 2013 gaven alle Surinaams-Nederlandse en Indonesisch-Nederlandse respondenten aan hun overledenen in Nederland te begraven en zelf ook de wens te hebben hier begraven te worden. Andere respondenten gaven daarentegen aan dat de band met het land van herkomst (van de (groot)ouders) een veel belangrijkere rol speelt bij de keuze van de begraafplaats dan de wettelijke en praktische mogelijkheden in Nederland. ${ }^{21}$ Dit gold destijds voor driekwart van zowel de Marokkaans-Nederlandse als de TurksNederlandse respondenten. Zij spraken de wens uit om gerepatrieerd te worden. Het gevoel te behoren tot Marokko dan wel tot Turkije en om daar begraven te worden in de nabijheid van de eigen ouders vormde hierbij de doorslaggevende overweging. De verschuiving binnen met name de tweede generatie Turks- en Marokkaans-Nederlandse moslims in hun keuze voor begraafplaats heeft ertoe geleid dat zij zelf de afgelopen jaren veelvuldig met concrete plannen en initiatieven zijn gekomen voor de realisering van nieuwe islamitische begraafplaatsen. Zoals in Zuidlaren. ${ }^{22}$

Het initiatief voor een islamitische begraafplaats in deze Drentse plaats kwam vanuit de stichting Bijzondere Islamitische begraafplaatsen in Nederland (Bibin). De stichting heeft zich tot doel gesteld om vijf islamitische begraafplaatsen in Nederland te realiseren: in Noord-Holland, Zuid-Holland, Brabant, Utrecht en Drenthe. Het initiatief wordt breed gedragen onder de Marokkaans-Nederlandse gemeenschap, zo blijkt uit de vele steunbetuigingen die Bibin ontving van

21 K. Kadrouch-Outmany, 'Burial practices and desires among Muslims in the Netherlands', Can. J. of Netherlandic Studies/Rev. can. d'études néerlandaises 2012-2013, p. 123-125.

22 Ik bespreek in dit artikel het voorbeeld van Zuidlaren. Daarnaast zijn er ook plannen in de gemeente Rotterdam voor een gezamenlijke begraafplaats met eeuwige grafrust voor zowel moslims als voor de liberaal joodse gemeenschap. Ook in Den Haag wordt de realisatie van een islamitische begraafplaats onderzocht op verzoek van de islamitisch politieke partij NIDA. 
bekende en minder bekende Marokkaanse Nederlands. ${ }^{23}$ Bibin wilde in Zuidlaren de grootste islamitische begraafplaats van West-Europa aanleggen. Op het 5400 vierkante meter grote perceel is plek voor 1400 graven met eeuwigdurende grafrust. Hoewel Bibin stelt dat de begraafplaats in Zuidlaren openstaat voor alle moslims, geeft de voorzitter wel te kennen dat de begraafplaats een soennitische begraafplaats is:

'De begraafplaats staat open voor alle moslims die de shahada hebben uitgesproken. Sjiieten volgen de profeet Ali en kunnen dus niet bij ons worden begraven. Ahmadiyya ook niet. Als je als moslim op deze begraafplaats begraven wilt worden, dan moet je je houden aan ons reglement. Wij zijn een soennitische begraafplaats, en willen een sobere begraafplaats inrichten. Gebruik van foto's en beelden bij grafzerken is niet toegestaan. Vergelijk ons met een militaire begraafplaats.'

De termijn voor het verzamelen van de benodigde gelden liep tot 1 juli 2020 . Begin maart 2020 had de stichting ruim $€ 312.000$ van de benodigde $€ 400.000$ ingezameld.

Deze tweede islamitische begraafplaats in Nederland werd uiteindelijk versneld gerealiseerd door de gevolgen van de Covid-19-crisis in het voorjaar 2020: het resterende geldbedrag van bijna een ton werd halverwege maart 2020 binnen een aantal dagen opgehaald. Bibin gaf in april 2020 aan te hopen de toentertijd meer dan 100 overledenen die in verschillende Nederlandse mortuaria lagen, spoedig hun laatste rustplaats te kunnen geven op de begraafplaats. Direct na de overdracht van het stuk land in april 2020 is Bibin begonnen met het gereedmaken van de begraafplaats. De bouw van een ontvangstruimte en de aanleg van paden werd uitgesteld. De prioriteit lag bij het gereedmaken van de graven, waarin meer dan honderd overledenen sinds eind april hun laatste rustplaats vonden.

\section{Het juridische verhaal: wat zijn de mogelijkheden?}

De begraafwereld in Nederland is in beweging. ${ }^{24}$ Mensen willen steeds meer een persoonlijke wending geven aan de uitvaart van hun dierbaren. Vaak kan dat, maar soms staat de wet in de weg. De Wet op de lijkbezorging regelt alle eisen rondom de uitvaart en is door de jaren heen op verschillende momenten herzien. In de initiatiefnota van voormalig D66-parlementariër Monica den Boer wordt gepleit voor een nieuwe Uitvaartwet die met de tijd meegaat en meer keuzevrijheid biedt. ${ }^{25}$ In de initiatiefnota wordt ook aandacht gevraagd voor nieuwe doel-

23 Zo wijdde de onder Marokkaans-Nederlandse jongeren zeer populaire vlogger Salahedinne Benchikhi meerdere items aan de realisering van de begraafplaats in Zuidlaren. Zie bijv. zijn vlog Op zoek naar een begraafplaats.

24 C. Harrems, De uitvaartplanner. Van stervensbegeleiding tot bedankkaart, Utrecht/Antwerpen 2012; E. Venbrux, M. Heessels \& S. Bolt, Rituele creativiteit. Actuele veranderingen in de uitvaart- en rouwcultuur in Nederland, Zoetermeer 2018.

25 Kamerstukken II 2018/19, 35077, nr. 1. 
groepen. Voor begraafplaatshouders, die hun begraafplaatsen ondanks de stijgende crematiecijfers kostendekkend willen houden, zijn mensen die een grote voorkeur hebben voor graven met onbepaalde grafrust, onder wie moslims, een belangrijke doelgroep. ${ }^{26}$ Jarenlang hebben islamitische gemeenschappen onderhandeld voor de realisatie van aparte percelen op bestaande begraafplaatsen. Tegenwoordig vragen zij minder vaak om een hoekje op de begraafplaats, of een islamitisch perceel, maar zetten islamitische gemeenschappen zich steeds meer in voor particuliere islamitische begraafplaatsen.

\section{Van Begraafwet, naar Wet op de lijkbezorging, naar een moderne Uitvaartwet}

De Wet op de lijkbezorging uit 1991 vormde een integrale herziening van de Begraafwet. ${ }^{27}$ De belangrijkste en tevens meest ingrijpende wijziging in de Begraafwet kwam tot stand in 1955, toen onder meer crematie werd opgenomen in de wet. ${ }^{28} \mathrm{Bij}$ die wijziging is ook de huidige citeertitel ingevoerd, omdat de wet voortaan niet uitsluitend bepalingen inzake begraving bevatte. $\mathrm{Na} 1991$ is de wet nog enkele malen gewijzigd. De belangrijkste wijziging was die van 1998, toen de regels rondom de as-bestemming werden versoepeld. ${ }^{29}$

In de initiatiefnota doet Monica den Boer langs twee pijlers een veertiental voorstellen om de wet te moderniseren. En om daarnaast de mensen meer keuze te bieden en meer vrijheid te geven de uitvaart naar persoonlijke wensen vorm te geven. Ik zal vier voorstellen bespreken die in het kader van dit artikel relevant zijn: (1) de mogelijkheid meerdere mensen in een kist te begraven of tegelijk te cremeren, (2) begraving of crematie al 20 uur na het overlijden mogelijk maken in plaats van 36 uur, (3) het instellen van toezicht op de uitvaartbranche, en ten slotte (4) het opstellen van een handleiding met kennis over de culturele achtergronden in Nederland.

Naar een nieuwe Uitvaartwet: de voorstellen

\section{- Meerdere personen in een graf}

De regel in Nederland is dat er één overledene in een kist begraven mag worden, en één persoon per keer gecremeerd mag worden. ${ }^{30}$ Daar staat tegenover dat nabestaanden soms twee mensen samen willen begraven of cremeren. De wet kan met name in het geval van een doodgeboren of kort na de geboorte overleden tweeling als beperkend en onbegrijpelijk worden ervaren. Hetzelfde geldt wanneer moeder en kind in het kraambed overlijden. Concreet wordt daarom voorgesteld om voor tweelingen (en andere meerlingen) die op enig moment gedurende de zwangerschap levenloos ter wereld komen, dan wel binnen 24 uur na de geboorte overlijden, de mogelijkheid te bieden om samen te worden gecre- 
meerd of begraven. Eveneens geldt dit voorstel voor de in het kraambed gestorven moeder en kind.

Dit punt kwam ook naar voren in de interviews die ik hield onder moslims in Nederland ten tijde van mijn onderzoek tussen 2010 en 2013. Een doodgeboren tweeling van 27 weken mocht niet samen in een graf begraven worden. Er moest volgens de regelgeving in ieder geval $30 \mathrm{~cm}$ tussen zitten, terwijl de ouders de kindjes nu juist zo graag tegen elkaar aan wilden begraven. De wet werd door deze ouders als enorm belemmerend ervaren. De onbekendheid met de regelgeving rondom een begraving in Nederland en de teleurstelling rondom de aparte graven maakten dat deze Marokkaans-Nederlandse ouders in de hectische tijd die zij doormaakten ook nog de optie overwogen om de tweeling in Marokko te laten begraven, in één grafje bij elkaar. Uiteindelijk prevaleerde voor de moeder vooral de mogelijkheid het graf van de kindjes te bezoeken. De tweeling werd in Nederland begraven in een graf met $30 \mathrm{~cm}$ tussen hen in, tot groot verdriet van de nabestaanden.

\section{- Begraaftermijnen}

In Nederland kan een begraving of crematie 36 uur ná het overlijden plaatsvinden. Soms hebben nabestaanden, onder wie veel moslims, de wens om al binnen 24 uur te begraven. Er kan hiervoor een beroep worden gedaan op de uitzonderingsregel, waarbij de burgemeester samen met de officier van justitie bepaalt of de overledene binnen 24 uur begraven mag worden. De nota stelt voor om het voor 'alle veelvoorkomende religies in Nederland mogelijk te maken het geloof te praktiseren zonder dat daar speciale procedures voor moeten worden gevoerd'. ${ }^{31}$ Er wordt voorgesteld om de termijn van 36 uur te verkorten naar 20 uur. Alleen indien een begraving in minder dan 20 uur gewenst is, geldt nog de procedure waarbij de uitzondering moet worden aangevraagd.

Dit punt is, samen met de kwestie van eeuwigdurende graven, een van de meest besproken wettelijke beperkingen die moslims ondervinden bij begraving in Nederland. Een islamitische begrafenis dient zo snel mogelijk plaats te vinden, bij voorkeur niet later dan de dag van overlijden. Zolang de overledene niet begraven is, heeft de ziel geen rust en geen mogelijkheid om over te gaan naar de wereld van het hiernamaals. Dit voorstel zal daarom tegemoetkomen aan de wens van een grote groep moslims in Nederland en daarmee een belangrijk verschil maken in de beleving van de religieuze plicht om de overledene zo snel mogelijk te begraven.

\section{- Toezicht op de uitvaartbranche}

Op dit moment is er geen formele toezichthouder op de naleving van de Wet op de lijkbezorging. Onderdelen van de wet zijn onderworpen aan bijvoorbeeld de Arbeidsinspectie en de Inspectie voor de Gezondheidszorg, maar veel andere aspecten blijven ongecontroleerd. Voorbeelden hiervan zijn het gebruik van het verleende verlof tot begraving dat wordt uitgegeven door de gemeente. Niemand weet of een overleden persoon daadwerkelijk begraven wordt op een begraaf- 
plaats of in de achtertuin. Daarnaast hebben uitvaartondernemers geen verplichte opleiding nodig om een bordje op de gevel te schroeven en zich uitvaartondernemer te noemen. In de initiatiefnota wordt voorgesteld te onderzoeken op welke manier toezicht kan worden ingesteld op de uitvaartbranche. Een aanvullende mogelijkheid is het wettelijk verplicht stellen van het aansluiten bij een branchevereniging van uitvaartondernemers.

In het geval van begrafenisondernemers die zich in het bijzonder richten op islamitische uitvaarten, zou dit voorstel wenselijk zijn. Veel nieuwe begrafenisondernemers zien namelijk ten aanzien van moslims een mogelijkheid om in een behoefte te voorzien, maar zijn niet altijd goed en volledig op de hoogte van de juridische en praktische mogelijkheden in Nederland. De respondenten die ik sprak ten tijde van mijn onderzoek tussen 2010 en 2013, maar ook recentelijk ten tijde van de Covid-19-crisis, waren in bijna de helft van de gevallen ontevreden over de uitvaartondernemer die zich gespecialiseerd noemde in islamitische begrafenissen. Ze vonden met name de communicatie gebrekkig, de mogelijkheden die aangereikt werden beperkt, en de culturele en theologische verschillen tussen de uitvaartondernemer en de familie soms te groot. Het zou daarom wenselijk zijn dat nieuwe uitvaartondernemers een opleiding volgen en praktijkuren maken, alvorens als uitvaartondernemer te mogen werken. In het geval van een islamitische begrafenis moeten regelmatig alle beslissingen rondom een uitvaart binnen 24 uur gemaakt worden. Gedegen geïnformeerd zijn met betrekking tot de wettelijke en praktische mogelijkheden is dan belangrijk. Bovendien zouden ook begrafenisondernemers die zich willen specialiseren in islamitische uitvaarten oog moeten blijven houden voor de diversiteit onder de islamitische gemeenschappen in Nederland, en dus geen theologische aannames moeten maken over de wensen van nabestaanden.

\section{- Handleiding diversiteit}

Ten slotte noem ik het voorstel waarin de minister van Binnenlandse Zaken wordt gevraagd in gesprek te treden met de brancheverenigingen om een handleiding op te stellen voor hun leden. Dit met het doel om rekening te houden met verschillende culturen in de Nederlandse samenleving. De initiatiefnota stelt zich een zo open mogelijke wet voor die geen belemmeringen opwerpt voor de aanwezige culturen en religieuze voorkeuren in Nederland. Afgezien van de vastgestelde tijd waarna begraven kan worden (wat door moslims wordt ervaren als een beperking), biedt de wet momenteel veel ruimte voor de verschillende gemeenten, uitvaartverzorgers, uitvaartondernemers, begraafplaatshouders en crematoriabeheerders om mensen over die ruimte te informeren en hen die ruimte te laten nemen. Een handleiding waarin kennis wordt gedeeld over de culturele achtergronden in Nederland, zou de uitvaartbranche beter kunnen voorbereiden op de diverse samenleving en de verscheidenheid aan wensen en voorkeuren. 


\section{Begraven in tijden van Covid-19}

Zolang het luchtruim gesloten blijft voor passagiersvluchten en repatriëringen zullen overleden moslims hun laatste rustplaats in Nederland moeten vinden. Daarvoor zal een groot beroep worden gedaan op de bestaande islamitische percelen en begraafplaatsen. Verschillende islamitische organisaties hebben zich tot hun plaatselijke bestuurders gericht met het verzoek het eeuwigdurende grafrecht te verlenen aan de Nederlandse moslims die vanwege het vliegverbod in Nederland begraven moesten worden. Het Rotterdamse college van burgemeester en wethouders besloot in maart 2020 daarom dat islamitische overledenen voor eeuwige grafrust terecht konden op de algemene begraafplaatsen. Ook in Amsterdam werd door een raadsmeerderheid gevraagd om te zorgen voor eeuwige grafrust op islamitische percelen. Het college van burgemeester en wethouders in Den Haag zegde in april 2020 een tijdelijke oplossing toe in de vorm van het afkopen van grafrechten voor 100 jaar en beloofde op zoek te gaan naar de mogelijkheden voor een particuliere islamitische begraafplaats.

Door Covid-19 kregen alle begraafplaatsen, zowel openbare met een islamitisch perceel als islamitische particuliere begraafplaatsen, dagelijks de zorg voor tientallen begrafenissen meer dan vóór de uitbraak van Covid-19. Begraafplaatsen gingen van een aantal islamitische begrafenissen per maand naar tientallen per week. Organisatorisch en praktisch vroeg dit in korte tijd om een enorm aanpassingsvermogen, zowel bij begraafplaatshouders als bij uitvaartondernemers en nabestaanden.

Op het moment van schrijven (juni 2020) mochten alle uitvaarten door maximaal 30 mensen worden bijgewoond, op anderhalve meter afstand van elkaar. ${ }^{32}$ Islamitische begrafenisrituelen zijn als gevolg van de pandemie komen te vervallen en andere werden gedigitaliseerd. Zo werden het begrafenisgebed en de begrafenis zelf regelmatig via livestream uitgezonden op sociale media, zodat nabestaanden in en buiten Nederland digitaal aanwezig konden zijn. ${ }^{33}$ Evenzo werden er vanwege de Covid-19-maatregelen geen lijkwassingen en inwikkelingen meer uitgevoerd, en werd de overledene altijd in een kist begraven. Van een bewuste keuze om in Nederland te begraven vanwege de Covid-19-maatregelen lijkt bovendien in veel gevallen helemaal geen sprake. Een van mijn respondenten verwoordde de beslissing om zijn vader, die in april 2020 overleed aan de gevolgen van Covid-19, in Nederland te begraven in de volgende anekdote:

'Mijn vaders ergste nachtmerrie, zijn worst-case-scenario was altijd om, wanneer hij zou komen te overlijden, te lang op een vlucht naar Marokko te moeten wachten. Hij zei dan altijd "mijn zoon, beloof me dat je mij niet te lang in de koelkast (mortuarium KKO) laat liggen en maak haast met mij te begraven". Aan de ene kant denk ik nu hij hier in Nederland is begraven: hij heeft in ieder geval niet lang in het mortuarium gelegen. Maar aan de andere kant valt de beslissing mij zwaar; mijn vader had nooit kunnen bedenken dat 
hem hier in Nederland begraven ook nog tot de categorie worst-case-scenario zou behoren.'

\section{Conclusie}

De keuze waar iemand begraven wil worden, onthult veel over hoe iemand zich verhoudt tot die plek. Door de Covid-19-crisis lijkt de discussie rond islamitisch begraven in Nederland die al jaren onder de oppervlakte sluimerde, nu duidelijk naar boven te drijven. De sluiting van het luchtruim heeft Nederlandse moslims gedwongen om een keuze te maken voor wat betreft de begraafplaats van hun overleden naasten. Gelijktijdig werden zij ook gedwongen na te denken over hun eigen keuze. Dat het mogelijk is gebleken om binnen een week bijna $€ 100.000$ te verzamelen onder moslims voor de aanleg van een islamitische begraafplaats, geeft ook aan dat de noodzaak om een keuze te moeten maken breed gedragen werd.

Ook is het belang gebleken van de herziening van de Wet op de lijkbezorging op punten waar Nederlandse moslims nog tegen aanlopen. Als begraving in Nederland volgens de religieuze voorschriften en juridische opties mogelijk is, zullen deze punten veel minder een rol gaan spelen bij de keuze voor de begraafplek. Wat dan resteert is daadwerkelijk een keuze maken.

Terwijl de islamitische begraafplaats in Zuidlaren nog maar nauwelijks looppaden heeft naar de graven toe, hebben in het bijzonder moslims uit de MarokkaansNederlandse gemeenschap alweer een volgend project voor ogen: in Utrecht de volgende islamitische begraafplaats realiseren. Met de toename van initiatieven voor islamitische begraafmogelijkheden zal de optie om in Nederland begraven te worden voor veel Nederlandse moslims ongetwijfeld geen scenario van de slechtst mogelijke afloop meer zijn, maar één van de weloverwogen opties. 